\title{
"Value relevance of financial statements and share price: a study of listed banks in Nigeria"
}

\begin{tabular}{|c|c|}
\hline \multirow{7}{*}{ AUTHORS } & Olubukola Ranti Uwuigbe (D https://orcid.org/0000-0002-6566-1083 \\
\hline & $\mathbb{R}$ http://www.researcherid.com/rid/G-2929-2018 \\
\hline & Uwalomwa Uwuigbe (D https://orcid.org/0000-0001-8769-3492 \\
\hline & R http://www.researcherid.com/rid/G-2903-2018 \\
\hline & Jimoh Jafaru \\
\hline & Ebeguki Edith lgbinoba \\
\hline & Olufemi Adebayo Oladipo (D https://orcid.org/0000-0003-4570-8996 \\
\hline ARTICLE INFO & $\begin{array}{l}\text { Olubukola Ranti Uwuigbe, Uwalomwa Uwuigbe, Jimoh Jafaru, Ebeguki Edith } \\
\text { Igbinoba and Olufemi Adebayo Oladipo (2016). Value relevance of financial } \\
\text { statements and share price: a study of listed banks in Nigeria. Banks and Bank } \\
\text { Systems, 11(4-1), 135-143. doi:10.21511/bbs.11(4-1).2016.04 }\end{array}$ \\
\hline DOI & http://dx.doi.org/10.21511/bbs.11(4-1).2016.04 \\
\hline RELEASED ON & Thursday, 22 December 2016 \\
\hline JOURNAL & "Banks and Bank Systems" \\
\hline FOUNDER & LLC "Consulting Publishing Company "Business Perspectives" \\
\hline
\end{tabular}

NUMBER OF REFERENCES

0

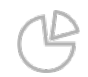

NUMBER OF FIGURES

0

\section{ニシ-}

NUMBER OF TABLES

0

(C) The author(s) 2023. This publication is an open access article. 
Olubukola Ranti Uwuigbe (Nigeria), Uwalomwa Uwuigbe (Nigeria), Jimoh Jafaru (Nigeria), Ebeguki Edith Igbinoba (Nigeria), Olufemi Adebayo Oladipo (Nigeria)

\title{
Value relevance of financial statements and share price: a study of listed banks in Nigeria
}

\begin{abstract}
This paper examined the effects of value relevance of financial statements on firms share price in Nigeria. In achieving the objectives of this research, the fact book from the Nigerian Stock Exchange Market and the audited financial statement of listed banks spanning the period 2010-2014 were used. Also, a total of 15 listed banks in the Nigerian stock exchange market were selected and analyzed for the study using the purposive sampling method. However, in analyzing the research hypotheses, the study adopted the use of both descriptive statistics and the use of Fixed Effects Panel data method of data analysis technique. Findings from the study showed that a significant positive relationship existed between earnings per share (EPS) and Last day share price (LDSP). The study recommends the need for banks in the country to improve on the quality of earnings reported, since it has a stronger ability to explaining share prices of firm.
\end{abstract}

Keywords: value relevance, financial statements, Nigerian, earnings per share, last day share, price, book value per share, accounting information.

JEL Classification: M41, G21.

\section{Introduction}

Organizations are basically responsible for the preparations of their financial statements and, thus, need to ensure that the statements represent the actual financial status or position of their firm. The main objective of accounting information is to help investors in making informed investment decision-making more effective and efficient. Consequently, financial statement fundamentally summarizes business transactions and other events, as they relate to the performance of organisations. Value relevance here is measured by its ability to summarize accounting information (Francis \& Schipper, 1999). For financial reports to be relevant, the information content must be relevant in investment decision-making. Thus, from an investor's perspective, only information that contributes to the investment decisions of an investor is important (Omokhudu \& Ibadin, 2015).

Value relevance as a notion is based on the pillars of relevance and reliability. It involves the ability of accounting numbers to summarize the information underlying the stock prices. It describes the relationship between financial information and stock prices (Liu \& Liu, 2007). Basically, listed firms use financial statements as one of their major avenue for communicating financial information to their shareholders and the public at large (Nassar, Uwuigbe, Uwuigbe \& Abuwa, 2014). Accounting information is described or seen as

\footnotetext{
(C) Olubukola Ranti Uwuigbe, Uwalomwa Uwuigbe, Jimoh Jafaru, Ebeguki Edith Igbinoba, Olufemi Adebayo Oladipo, 2016.

Olubukola Ranti Uwuigbe, Department of Accounting, Covenant University, Ota-Ogun, Nigeria.

Uwalomwa Uwuigbe, Department of Accounting, Covenant University, Ota-Ogun, Nigeria.

Jimoh Jafaru, Accountancy Department, Auchi Polytechnic, Auchi, Edo State, Nigeria.

Ebeguki Edith Igbinoba, Department of Business Management Covenant University, Ota-Ogun, Nigeria.

Olufemi Adebayo Oladipo, Accounting and Finance, Landmark University, Omu Aran, Nigeria.
}

relevant when it influences the users' decisions to form an opinion (Uwalomwa, Uwuigbe \& Okorie, 2015). It ensures that firms remain credible in the mind of investors and shareholders. Value relevance needs to be accessed in order to determine the usefulness of financial information to investors (Papadaki \& Siougle, 2007). The market valuation of a firms stock is one of the most important criteria in describing a firm's value. Therefore, the maximization of prices of a firm stock is the main aim of most organizations in achieving their credibility and reliability in the mind of investors. Consequently, the value of a firm is based on how the market perceives its performance.

Extant studies on value relevance of accounting information have recently pinched attention of both the academia and practitioners, precisely, during the global financial crisis of 2007-2009 (Krishnan and Krishnan, 2013; Uwuigbe, Uwuigbe \& Daramola, 2014). Prior research from relevant literatures show that the importance of the capital market can never be overemphasized, since it serves as an engine of growth and development to any economy. Over the years, extant literatureshave examined the value relevance of accounting information. For example, Collins et al. (1997) avowed that due to the transition from industrialized economy to high-tech oriented economy, financial statements have lost their relevance. However, there are contradicting opinions or inferences on the direction of change in value relevance. Francis and Schipper (1999) in a related study noted an increasing trend in the value relevance of accounting information. On the contrary, Lev and Zarowin (1999), Core et al. (2003), Vishnani \& Shah (2008), Kormendi \& Lipe (1987), Sharma, Kumar and Singh (2012) in a related study avowed a decline in the value relevance of accounting information. This lacuna in the literature coupled with the series of major corporate failures and financial scandals in the US, Europe and Africa provides 
a basis for this study from an emerging economy like Nigeria that is currently experiencing recession and coupled with the continuous fall in prices of stock in the capital market. This study thus, investigates the effects of value relevance of financial statements on firms share price in Nigeria.

The remaining part of this paper has been organized as follows: section 1 basically looked at extant literatures relevant to this study and the development of hypotheses to be tested in the study. Section 2 describes the methodology adopted for the study. Section 3 provides discussion of the various findings, while final section provides insights into the conclusion and recommendations from the study.

\section{Conceptual framework}

1.1. Concept of value relevance. A financial statement (or financial report) is a formal record of the financial activities and position of a business, person, or other entity. Relevant financial information is presented in an organized manner and in a form easy to comprehend. Financial statements have the ability to perform a number of functions. They basically provide financial aid to managers in decision-making, measurement or evaluation of a firm's performance, and also to portray a firm's value. Thus, for disclosed financial information to be useful, it must be relevant and faithfully represent what it purports to represent. The usefulness of financial information is enhanced if it is comparable, verifiable, timely and understandable (Conceptual Framework, 2010).

A state of "value-irrelevance" occurs if the financial figures or information obtained from the annual reports of companies do not affect or determine the stock prices, stock returns or other market indicators (Vishnani \& Shah, 2008). While some studies have ascertained that certain accounting numbers show stronger relationships between share prices, others show weak relationships, and some even show a negligible relation when compared. Highlights on the value relevance of financial statements research, can be traced to the works of Ball and Brown (1968), Ohlson (1995), and a few other accounting researchers. These researchers proved that stock prices, returns, and other stock market indicators are associated with accounting numbers (Liu \& Liu, 2007). According to Francis \& Schipper (1999), there are four diverse methods to view financial statement value relevance. The first view is characterized by the determination of the value of a company's shares or securities through fundamental analysis. Fundamental analysis involves analyzing financial statements to determine a firm's value and growth potential. Companies look into their financial, economic and qualitative factors, in an attempt to carry out fundamental analysis and, in the process, determine their intrinsic value.
According to Francis \& Schipper (1999), the determination of the value will eventually affect the market prices and cause market prices to drift. Hence, the market share price or value eventually digresses towards the calculated intrinsic share value (Nilsson, 2003; Ou \& Penman, 1989). Ou \& Penman (1989) opined that the intrinsic share values calculated identifies values that the market share prices do not contain. This is why Nilsson (2003) classified this view as the fundamental analysis view of value relevance. On the long run, value relevance occurs, since the financial statement information that underwent fundamental analysis will eventually affect stock prices. In the second interpretation, value relevance occurs when accounting variables are predicted and used in valuation models. Information in accounting is described as relevant if it helps to provide or determine values related to a valuation model or theory. In the third view, accounting information is value relevant, if it aids investors in determining share prices or valuing shares. In Nilsson's perspective, this third view, which he calls information view of value relevance proffers that accounting information is value relevant if it causes the market value of shares to fluctuate once it is released (Nilsson, 2003). Nilsson calls the fourth view Francis and Schipper (1999) put forward the measurement view of relevance (Nilsson, 2003). Here, value relevance of financial statements is seen as the ability of accounting data to provide information, relating to the firm's value. This view believes that value relevance can be measured by the total market reaction to accounting variables.

1.2. The Nigerian capital market. The capital market is simply described as a market that offers services for mobilizing and dealing in medium and long-term funds. The actors on the capital market are the operators who act as mediators amid the providers of the funds and the fund users. They include, Securities Exchanges, Brokers/Dealers, Issuing Houses, Registrars and Investment Advisors. It also provides an avenue to channel the wealth of savers to those who can put it to long-term productive use. In an attempt to make funds available and accessible for economic development and growth, the Securities and Exchange Commission was established in 1979 by the Securities and Exchange Commission Decree (this decree was re-enacted in 1988 as Securities and Exchange Commission Decree no. 29 of 1988. The basic idea is to protect investors as well developing the capital market. Currently, is guided by the the Investments and Securities Act, 2007 which aims at providing a more efficient and viable capital market positioned to meet the country's economic and developmental needs. 
1.3. Securities and Exchange Commission. The Securities and Exchange Commission by virtue of Section 13 of the Investment and Securities Act (ISA) 2007, is the apex regulatory agency for the Nigerian capital market. Originally established by SEC Decree 29 of 1988, the Commission has evolved over the years with its current enabling law being the Investment and Securities Act (ISA) 2007. The Commission is basically charged with the dual role of developing and regulating the market.

1.4. Roles and functions of Securities and Exchange Commission. The following are some of the specific functions that the Securities and Exchange Commission is charged with as listed in section 13 of the Act:

- regulating investments and securities in Nigeria as defined in the Act;

- registration and regulation of Securities Exchange, Capital Trade Points, and Futures, Options and Derivative Exchanges and any other recognized Investment Exchange;

- registration of securities to be offered for subscription or sale to the public;

- rendering assistance to all aspects including funding as may be deemed necessary to promoters and investors wishing to establish Securities Exchange and Capital Trade Points;

- preparing adequate guidelines and organizing training programs and disseminating information necessary for the establishment of Securities Exchange and Capital Trade Points;

- registering and regulating corporate and individual capital market operators as defined in section 30 of the Decree;

- register and regulate the workings of Venture Capital Funds and collective investment scheme including mutual funds;

- facilitate the establishment of a nationwide system for securities trading in the Nigerian Capital Market in order to protect investors and maintain fair and orderly markets, etc.

\section{Literature review and development of hypotheses}

The value relevance of financial information is one of the most addressed issues in accounting research. It is enthused primarily by the desire to provide empirical evidence as to whether users find accounting information relevance in their investment decisions. Cready \& Myanatt (1991), in their study, observed that share prices of firms and value relevance of earnings are related, but findings from their study showed that individual investors rely on earnings a lot more than institutional investors do. Also, Gaston, Fernadez, Harne \& Gadea (2003), in a related study, observed that disaggregation of earnings into components parts of income statement provided investors with incremental information regarding market value of companies. Simi- larly, Wulandri \& Rahman (2004) observed a positive association between value relevance of earnings and quality of accounting standards, acceptability of standards and punitive enforcement of the standards. They also found out that accounting institutional environment has a stronger positive association with value relevance of accounting earnings than legal environment. In a related study, Hadi (2004), in a study conducted in Kuwait, observed that accounting information is very useful to investors in Kuwaiti banks, and most ratios are significant except the loss ratio. Ortega (2006) reinvestigated the changes in value relevance of earnings book values and cash flows in security prices over time. Employing data from 1961 to 2005 extracted from Compustat primary, secondary and tertiary full coverage and research annual industrial files. Findings from the study showed that cash flow provides incremental information content beyond earnings and book values in security prices.

In the same vein, Ben Naceur \& Nachi's (2007) avowed that earnings, cash flows and book values are significantly influences share prices. They also observed that value relevance of accounting information has improved and that the factors of firm size and branch of activity have not improved the value relevance of accounting information in the Tunisian Stock Exchange following the accounting reforms. Similarly, Mohammadi et al. (2012) documented that that there is no relationship between accounting information and companies' value. In the same vein, Pervan (2012) using a sample of 97 corporations analyzed the value relevance of accounting information on the capital markets of Southeast Europe. Documented evidence from the research indicated that accounting information are value relevant on all the observed markets. In addition, the study observed that there were certain differences in the value relevance among countries. Also, Andriantomo \& Yudianti (2013), in a related study showed that earnings and book values simultaneously are relevant information in explaining stock prices.

However, contrary to the findings in earlier research, Abayadeera (2010) examined the value relevance of financial and non-financial information in high-tech industries in Australia with a sample size of $91 \mathrm{com}-$ panies running through various sectors of the Australian economy. Findings from the study indicated that value relevance declined in earnings, but increased in book value. Similarly, Lev \& Zarowin (1999), Core et.al (2003), Vishnani \& Shah (2008), Kormendi \& Lipe (1987), Sharma, Kumar and Singh (2012), in a related study, observed a decline in the value relevance of accounting information. In the same vein, findings from Core, Guay \& Buskirk (2003) revealed a declining value relevance of accounting information. This lacuna in the literature basically provides a basis for this study. 
2.1. Development of hypotheses. Based on the evidence of a declining value relevance of accounting information coupled with the lacuna in extant literature, the following hypotheses stated in the null form will be tested in this study.

- $H_{1}$ : Earnings per share do not significantly affect share prices of firms listed on the Nigerian Stock Exchange.

- $\mathrm{H}_{2}$ : Book value per share has no significant impact on stock prices of firms listed on the Nigerian Stock Exchange.

- $H_{3}$ : There is no significant relationship between return on net worth and share prices of firms listed on the Nigerian Stock Exchange.

\section{Methodology}

In achieving the objectives of this research, data from the Nigerian Stock Exchange, Fact book and audited annual financial statement of the selected listed banks covering the period 2010-2014 were analyzed. The choice of these periods arises based on the capital market crash observed during the period coupled with the plethora of corporate frauds cases observed during the period. More so, using the purposive sampling technique a total of 15 listed banks were selected based on the availability of data. However, the study employed the use of Fixed Effects Panel data method of analysis technique. This is due to the fact that it provides researchers with large number of data and allows variables to be observed across time. In addition, according to Hsiao (2014), a longitudinal or panel data set is one that follows a given sample of individuals over time, and thus provides multiple observations on each individual in the sample.

3.1. Model specification. In order to examine the relationship between value relevance of financial statements and share prices of firms, a Modified Edwards Bell Ohlson (EBO) model equation was used. The EBO model is adapted and modified to suit the study. The two constructs involved include value relevance of financial statements and share prices of firms Listed on the Nigerian Stock Exchange.

The EBO model adapted is represented as (Maska, 2011):

$S P=\beta_{0}+\beta_{1} B V P S+\beta_{2} B E P S+e$,

where $S P$ - dependent variable (share prices of firms listed), $E P S$ - earnings per share, $B V P S$ - book value of equity capital, $\beta_{0}$ - intercept, $\beta_{1}$ and $\beta_{2}$ - regression coefficients with unknown values, $e$ - error term.

Explicitly, this equation (1) can be defined as;

Share Price $=f$ (Value Relevance of financial statement) $+e$.
The modified EBO model contains the additional variable, return on net worth. Hence, by representing equation two (2) with the variables of the EBO and addition of Return on net worth (RONW), the equation below is formulated. This is to enhance a better predictability and analysis of the relationship existing between the two constructs, share prices of listed firms and financial statements. The equation then becomes;

$L D S P=f$ (earnings per share, book value, return on net worth).

The above can be expressed as:

$L D S P=\beta_{0}+\beta_{1} E P S_{1}+\beta_{2} B V P S_{2}+\beta_{3} R O N W_{3}+$
$+e_{i t}$.

where $L D S P$ - last day share price, $E P S$ - earnings per share, $B V P S$ - book value of equity capital, $R O N W$ - return on net worth, $\beta$ - coefficient of parameters, $e$ - error term, which captures other explanatory variables not explicitly included in the model.

\section{Discussion of findings}

The descriptive statistics as presented in Table 1, shows the summary of a five years means and standard deviations for the variables employed in the study. The results obtained from the descriptive statistics presents an average mean value for (last day share price (LDSP) as 8.87, with minimum and maximum values of 0.53 and 27.27, respectively, for the selected banks. The standard deviation stood at 7.08, indicating the dispersion in values for market share price from the mean across the sample banks. Similarly, descriptive results on the earnings per share (EPS) show an approximate mean value of 1.02 , with a standard deviation is 1.16 . The table also presents an approximate mean value for book value pershare (BVPS) as 62.10, with an approximate standard deviation value of 217.6402. In the same vein, the table also presents the results of the return on net worth (RONW) with a mean value of $10.82 \%$, which is as a result of fluctuations in profit, and increasing levels of equity. It also provides a standard deviation value of 13.57229 .

Table 1. Descriptive statistics

\begin{tabular}{|l|c|c|c|c|c|}
\hline Variables & $\begin{array}{c}\text { Observa- } \\
\text { tions }\end{array}$ & Mean & Std. Dev. & Min & Max \\
\hline LDSP & 75 & 8.8712 & 7.075867 & .53 & 27.27 \\
\hline EPS & 75 & 1.018743 & 1.162951 & -3.05 & 3.47 \\
\hline BVPS & 75 & 62.10171 & 217.6402 & .0997049 & 1071.12 \\
\hline RONW & 75 & 10.80859 & 13.57229 & -62.27 & 33.98 \\
\hline
\end{tabular}

Note: LDSP = last day share price, EPS = earnings per share, BVPS = book value per share, RONW = return on net worth.

Source: computed output STATA 14 (2016).

Multicollinearity tests/correlation analysis results. The test for multicollinearity was carried out before analyzing the regression model. According to Field (2000), this test is necessary, because mul- 
ticollinearity can affect the parameters of a regression model. Adeyemi \& Fagbemi (2010) and Uwuigbe, et al. (2015) suggested that a tolerance value less than 0.1 indicates a serious multicollinearity problem between the independent variables. Nevertheless, since all values are more than 0.10 , there is no issue of multicollinearity between the independent variables, as depicted in Table 2. Also, Myers (1990) suggested that a variance inflation factor (VIF) value greater than 10 calls for concern, however, for this study, the VIF values are less than 10 .

Table 2. Variance inflation factor

\begin{tabular}{lll}
\hline Variable & VIF & $I / V I F$ \\
\hline EPS & 1.37 & 0.727652 \\
RONW & 1.37 & 0.728415 \\
BVPS & 1.00 & 0.998767 \\
\hline Mean VIF & 1.25 & \\
\hline
\end{tabular}

Source: computed output STATA 14 (2016).

Table 3. Test of correlation between dependent and independent variables

\begin{tabular}{lllll}
\hline Variable & EPS & BVPS & RONW & _cons \\
\hline EPS & 1.0000 & & & \\
BVPS & -0.0343 & 1.0000 & & \\
RONW & -0.5211 & 0.0113 & 1.0000 & \\
_CONS & -0.3772 & -0.1853 & -0.2851 & 1.0000 \\
\hline
\end{tabular}

Note: LDSP = last day share price, EPS = earnings per share, BVPS = book value per share, $\mathrm{RONW}=$ return on net worth.

Source: computed output STATA 14 (2016).

Econometric analysis. In carrying out the econometric analysis, the Hausman test was conducted to determine whether the fixed effect or the random effect is most suitable for our regression analysis. The null and alternative hypothesis of the Hausman test is specified as follows:

$H_{0}=\operatorname{var}(b)=\operatorname{var}(B)=$ there is a correlated random effect,

$H_{I}=\operatorname{var}(b)=\operatorname{var}(B)=$ there is no correlated random effect.

The null hypothesis states that there is a correlated random effect which signifies that the random effect estimates are preferred to the fixed effects estimates, while the alternative hypothesis states that there is no correlated random effect which signifies that the fixed effects estimates are preferred to those of the random effects estimates. However, the rule of thumb for the Hausman diagnostic test is that if the probability of $\mathrm{chi}^{2}<0.05$, then, it is significant and the null hypothesis is rejected, while the alternative hypothesis accepted, conversely, if the probability of $\mathrm{chi}^{2}>0.05$, then, it is not significant and the null hypothesis is accepted, while the alternative hypothesis is rejected. Result from the Hausman test as depicted in Table 4 , shows that fixed effect method is selected, since the value of probability of $\mathrm{chi}^{2}<0.05$.

Table 4. Hausman test

\begin{tabular}{|c|c|c|c|c|}
\hline Variable & $\begin{array}{l}\text { Coefficients } \\
\text { (b) } \\
\text { Fixed }\end{array}$ & $\begin{array}{l}\text { (B) } \\
\text { Random }\end{array}$ & $\begin{array}{l}(b-B) \\
\text { Difference }\end{array}$ & $\begin{array}{l}\operatorname{sqrt}\left(\operatorname{diag}\left(V_{-} b-V_{-} B\right)\right. \\
\text { S.E. }\end{array}$ \\
\hline$\overline{E P S}$ & 1.53155 & 2.09239 & -568408 & \\
\hline$B V P S$ & -.0051003 & -.0032185 & -.0018818 & \\
\hline RONW & -.0422411 & -.0358987 & -.0063423 & \\
\hline Prob $>c h i^{2}$ & $=0.0000$ & & & \\
\hline
\end{tabular}

Note: LDSP = last day share price, EPS = earnings per share, BVPS = book value per share, RONW = return on net worth.

Source: computed output STATA 14 (2016). 
Table 5. Regression result

\begin{tabular}{lllll}
\hline Variable & Coefficients & $\begin{array}{l}\text { Pooled OLS } \\
\text { Random }\end{array}$ & Coefficients & $\begin{array}{l}\text { Fixed Effect } \\
\text { Significant Value }\end{array}$ \\
\hline EPS & 4.037555 & 0.000 & 1.53155 & 0.003 \\
BVPS & 0.0017546 & 0.556 & -0.0051003 & 0.026 \\
RONW & -0.0300186 & 0.592 & -0.0422411 & 0.234 \\
CONSTANT & 4.973469 & 0.000 & 8.084251 & 0.000 \\
R-Squared & 0.4090 & & 0.2195 & \\
Adjusted R-squared & 0.3841 & & & \\
F-statistic & 16.39 & & 6.54 & \\
Sig (F statistics) & 0.0000 & & 0.0007 & \\
\hline
\end{tabular}

Note: $\mathrm{LDSP}=$ last day share price EP S = earnings per share, BVPS = book value per share, $\mathrm{RONW}=$ return on net worth.

Source: computed output STATA 14 (2016).

Empirical findings from the regression analysis based on the panel data, as presented in Table 5, reports the association between the dependent variable (LDSP) and the independent variables (EPS, BVPS, RONW). Results of the goodness of fit test, as shown in Table 5 present an adjusted R2 value of about 0.3841 . This result implies that the value of the dependent variable (last day share price) can be explained by about 38\% of the independent variables. This value can be considered sufficient, because the dependent variable is also influenced by other predictors beside the variables used in this study (EPS, BVPS, RONW). Similarly, result on the F-statistic test (Fishers - test), which provides the test of the overall significance of the regression model as depicted in Table 5 presents a p-value that is less than 0.05 (i.e. p-value $<0.05$ ) for both the Pooled OLS and Fixed Effects respectively. This outcome basically suggests clearly that simultaneously, the explanatory variables are significantly associated with the dependent variable. In other words, the Fstatistics prove the validity of the estimated models which are statistically significant.

Empirical findings from Table 5 suggest that consistent with our a priori expectations (i.e., $\beta 1>0$ ), a significant positive relationship exist between earnings per share (EPS) and last day share price (LDSP). This outcome is evident in the coefficient of both the pooled OLS and fixed effect values of 4.0375 and 1.5315 , respectively. More so, the probability values $(\mathrm{P}>|\mathrm{t}|)$ of both the pooled OLS and fixed effect for earnings per share (EPS) as depicted in the table are, both significant at $1 \%$. Thus, earnings per share significantly affect share prices of firms listed on the Nigerian Stock Exchange. This outcome basically suggests that a unit increase in earnings per share (EPS) would result in an increase in LDSP by 1.53 Naira. In essence, the higher the earnings per share, the higher the share prices of firms. This outcome supports the methodological juxtaposition of Ijeoma (2015), AlShubiri (2010), Khanagha et al. (2011), Ernest and
Oscar (2014) and Ramen (2010), where it was observed that earnings per share are positively sensitive to share price of firms. Also, the result is consistent with the findings of Ahmad (2011), where it was observed that earnings per share contribute positively to financial reporting. However, findings from the second hypothesis suggest that there is a significant negative relationship between book value per share (BVPS) and last day share price (LDSP) of firms listed on the Nigerian Stock Exchange. This is evident in the probability value of the fixed effect $(P>|t|$ for BVPS and it is significant at 5\%, noting that fixed effects analysis is a better test for panel data according to Baltagi (2008). This outcome implies that a unit increase in the book values per share (BVPS) of the sampled firms would result in a decrease in last day share price (LDSP) by 0.5 kobo. This result is in consonance with the findings of Pourheydari, Aflatooni \& Nikbakhat (2008), where it was shown that book value per share was negatively sensitive to share prices of firms.

Conversely, findings from the third hypothesis, as depicted in Table 5 shows that the relationship between return on net worth (RONW) and last day share price (LDSP) is not significant. This outcome is evident in the probability value $(\mathrm{P}>|\mathrm{t}|)$ for return on net worth (RONW) which is neither significant at $1 \%, 5 \%$, or $10 \%$. Hence, the study accepts the null hypothesis which states that there is no significant relationship between return on net worth and last day share price.

\section{Conclusion}

This study examined basically the value relevance of financial statements and share price in Nigeria. Findings from the study show that a significant positive relationship exists between earnings per share (EPS) and last day share price (LDSP). This, however, indicates that earnings per share have a stronger ability to explain the variation in share prices relative to book value per share. Also, it was observed that a significant 
negative relationship exist between book value per share (BVPS) and last day share price (LDSP) of firms listed on the Nigerian Stock Exchange. However, the relationship between return on net worth (RONW) and last day share price (LDSP) was not significant. The study, thus, recommends the need for firms to improve on the quality of earnings reported, since it had a stronger ability to explaining share prices of firm. In addition, it is expected that listed banks on the Nigerian Stock Exchange, should display their earnings per share conspicuously in their presentation to investors and analysts and also include their book value per share. This will, on the long run, assists financial analysts and other interested parties in easy determination of firm's shareprices.

Limitation of study. Considering only the banking sector in this study is a major limitation. Hence, this study suggests that future research in this area could address this salient limitation by examining firms in other sectors of the Nigerian economy, especially the manufacturing sector.

\section{References}

1. Abayedeera, N. (2010). Value relevance of information in hi-tech industries in Australia: Accounting information and intangible assets disclosure, Global Review of Accounting and Finance, 1 (1), pp. 77-99.

2. Adeyemi, S.B. \& Fagbemi, T.O. (2010). Audit quality, corporate governance and firm characteristics in Nigeria, International Journal of Business and Management, vol. 55, pp. 169-179.

3. Al-Shubiri, F.N. (2010). Analysis of the relationship between working capital policy and operating risk: An empirical study on Jordanian industrial companies, Investment Management and Financial Innovations, 7 (2), pp. 167-176.

4. Ball, R. \& Brown, P. (1968). An Empirical Evaluation of Accounting Income Numbers, Journal of Accounting Research, 6 (2), pp. 159- 178.

5. Baltagi, B. (2008). Econometric analysis of panel data (Vol. 1). John Wiley \& Sons.

6. Barth, M., Beaver, W.H. \& Landsman, W.R. (1998). The relevance of the value relevance literature for financial accounting standard setting: Another view, Journal of Accounting and Economic, 31 (1-3), pp. 77-104.

7. Collins, D.W., Maydew, E.L. \& Weiss, I.S. (1997). Changes in the value- relevance of earnings and book values over the past forty years, Journal of Accounting \& Economics, 24 (1), p. 39.

8. Core, J.E., Guay,W.R. \& Burskirk, A.V. (2003). Market valuation in the new economy: an investigation of what has changed. Journal of Accounting and Economics, 34 (1), pp. 43-67. http://dx.doi.org/10.1016/S0165-4101 (02)00087-3.

9. Cready, W.M. \& Mynatt, P.G. (1991). The information content of annual reports: a price and trading response analysis, Accounting Review, 66 (2), pp. 291-312.

10. Ernest, O. \& Oscar, M.C. (2014). The Comparative Study of Value Relevance of Financial Information in the Nigeria Banking and Petroleum Sectors, Journal of Business Studies Quarterly, 6 (1), p. 42.

11. FASB. (1976). Elements of Financial Statements and Their Measurement. (Stamford, CT:FASB), December 2.

12. Francis, J, LaFond, R., Olsson, P. \& Schipper, K. (2004). Cost of capital and earnings attributes, Accounting Review, pp. 79-96.

13. Francis, J. \& Schipper, K. (1999). Have financial statements lost their relevance? Journal of accounting Research, pp. 319-352.

14. Gaston, S.C., Fernadez, B.C., Harne J.I. and Gadea, J.A.L. (2003). The Valuation of Earnings Components by the Capital markets: An International Comparison. Documento de Trabajo.

15. Hadi, M.M. (2004). The Importance of Accounting Information to the Investors in banking sector: Kuwaiti Evidence by Kuwait University.

16. Hsiao, C. (2014). Analysis of panel data. Cambridge University press. http://dx.doi.org/10.2307/2491413.

17. Ijeoma, N.B. (2015). Value Relevance of Accounting Information on Share Prices of Listed Firms, Social and Basic Sciences Research Review, 3 (10), pp. 328-344.

18. Jagan Krishnan, Chan Li, and Qian Wang. (2013). Auditor Industry Expertise and Cost of Equity, Accounting Horizons, 27 (4), pp. 667-691. http://dx.doi.org/10.2308/acch-50513.

19. Jennifer, F., Donna, P. \& Katherine, S. (1994). Shareholder Litigation and Corporate Disclosures, Journal of Accounting Research, 32 (2), pp. 137-164.

20. Khanagha. J.B., (2011). Value Relevance of Accounting Information in the United Arab Emirates, International Journal of Economics and Financial Issues, (1), pp. 33-45.

21. Kormendi, R. \& Lipe, R. (1987). Earnings innovations, earnings persistence, and stock returns, Journal of Business, 60 (3), pp.323-345.

22. Lev, B. \& Zarowin, P. (1999). The boundaries of financial reporting and how to extend them, Journal of Accounting Research, 37 (2), pp. 353-385.

23. Liu, J. \& Liu, C. (2007). Value relevance of accounting information in different stock market segments: The case of Chinese A-, B-, and H-shares, Journal of International Accounting research, 6 (2), pp. 55-81.

24. Maska, A. (2011). Assessment of value relevance of financial reports in the Nigerian Deposit Money Banks (Doctoral Dissertation).

25. Mohammadi, A. (2012). The Investigation of Relationship between Accounting Information and the value of companies (a case study). Available at: http://www.icndbm.com/pdf/129.pdf. 
26. Myers, R. (1990). Classical and modern regression with application (2nd), Boston Duxbury.

27. Naceur, B. \& Nachi, W. (2007). Does the Tunisian Accounting Reform Improve the Value Relevance of financial information? Online. Available at: http://www.adoptifrs.org/uploads/Tunisia/Does\%20the\%20Tunisian\%20 accounting\%20reform $\% 20$ improve $\% 20$ the $\% 20$ value $\% 20$ releva.pdf.

28. Nassar, L.M., Uwuigbe, O.R., Uwuigbe, U. and Abuwa, J.T. (2014). IFRS Adoption and Its Integration into Accounting Education Curriculum in Nigerian Universities, Research Journal of Finance and Accounting, 5 (22), pp. 76-82.

29. Nilsson, H. (2003). Essays on the value relevance of financial statement information.

30. Journal of Financial Economics, 38, pp. 63-84.

31. Ohlson, J.A. (2005). On Accounting-Based Valuation Formulae, Review of Accounting studies, 10 (2-3), pp. $323-347$.

32. Ohlson, J.A., \& Lopes, A.B. (2007). Accounting based valuation formulae. Brazilian Business Review (English Edition), 4 (2).

33. Ohlson, J.A. (1995). Earnings, book values, and dividends in equity valuation, Contemporary Accounting Research, 11, pp. 661-687.

34. Omokhudu, O.O. \& Ibadin, P.O. (2015). The Value Relevance of Accounting Information: Evidence from Nigeria, Accounting and Finance Research, 4 (3), p. 20.

a. Ortega, X. (2006). Reinvestigation of value relevance of earnings, book values and cash flow in security prices over time. Retrieved at: ccsenet.org/journal/index.php/ijbm/article/download/3186/.

35. Ou, J.A. \& Penman, S.H. (1989). Financial statement analysis and the prediction of stock returns, Journal of Accounting and Economics, 11, pp. 295-33.

36. Papadaki, A. \& Siougle, G. (2007). Value relevance of price, earnings and book values in the Athens Stock Exchange, Managerial Finance, 33 (5), pp. 309-320.

37. Pervan, I. (2012). Utilization of Accounting Information for Decision making in Croatian SME: Preliminary Findings, The Business Review, Cambridge, 19 (2), pp. 165-171.

38. Pervan, I. \& Bartulović, M. (2013). Impact of transparency level on the value relevance of accounting information: empirical analysis for SEE countries. izlaziusamo elektroničkom izdanju: NE.

39. Pourheydari, O., Aflatoon, A. \& Nikbakhat, Z. (2008). The pricing of dividends and book value in equity valuation: The case of Iran, International Research Journal of Finance and Economics, 13, pp. 1450-2887.

40. Sharma, A.K., Kumar, S. \& Singh, R. (2012). Value Relevance of Financial Reporting and Its Impact on Stock Prices: Evidence from India, South Asian Journal of Management, 19 (2), pp. 60-77.

41. Uwalomwa, U., Uwuigbe, O. \& Okorie, B. (2015). Assessment of the Effects of Firms' Characteristics on Earnings Management of Listed Firms in Nigeria. Asian Economic and Financial Review, 5 (2), pp. 218-228.

42. Uwuigbe, U., Uwuigbe, O.R. \& Daramola, P.S. (2014). Corporate governance and capital structure: evidence from listed firms in Nigeria Stock Exchange. Advances in Management, vol. 7 (2), pp. 44-49.

43. Vishnani, S. \& Shah, B.K. (2008). Value relevance of published financial statements-with special emphasis on impact of cash flow reporting, International Research Journal of Finance and Economics, 17 (1), pp. 84-90.

44. Waalandri, E.R. \& Rahman, A.R. (2004). A Cross Country Study on the Quality Acceptability and Enforceability of Accounting Standards and the Value Relevance of Accounting Earnings, Journal of Accounting Research, 42 (2), pp. 304-31. 
Appendix

Table 1. List of banks examined

\begin{tabular}{|l|c|}
\hline \multicolumn{1}{|c|}{ S/N } & SELECTED LISTED BANKS \\
\hline 1 & ACCESS BANK PLC \\
\hline 2 & DIAMOND BANK \\
\hline 3 & ECOBANK TRANSNATIONAL \\
\hline 4 & FBN HOLDINGS PLC \\
\hline 5 & FCMB GROUP PLC \\
\hline 6 & FIDELITY BANK PLC \\
\hline 7 & GUARANTY TRUST BANK PLC \\
\hline 8 & STANBIC IBTC HOLDINGS PLC \\
\hline 9 & STERLING BANK PLC \\
\hline 10 & SKYE BANK PLC \\
\hline 11 & UNION BANK NIG PLC \\
\hline 12 & UNITED BANK FOR AFRICA PLC \\
\hline 13 & UNITY BANK PLC \\
\hline 14 & WEMA BANK PLC \\
\hline 15 & ZENITH INT'L BANK PLC \\
\hline
\end{tabular}

